\title{
Verification of a Methodology for Targeting Brush Control to Maximize Water Yield Through Hydrologic Modeling
}

\author{
Jason D. Afinowicz \\ Department of Biological and Agricultural Engineering, Texas A\&M University \\ Clyde L. Munster \\ Department of Biological and Agricultural Engineering, Texas A\&M University \\ Bradford P. Wilcox \\ Department of Rangeland Ecology and Management, Texas A\&M University \\ Written for presentation at the \\ 2003 ASAE Annual International Meeting \\ Sponsored by ASAE \\ Riviera Hotel and Convention Center \\ Las Vegas, Nevada, USA \\ 27- 30 July 2003
}

\begin{abstract}
Brush control strategies have been implemented for many traditional grasslands that have been impaired by wooded species. However, little information is known concerning what site specific characteristics may be most beneficial for increasing water yields by returning shrub encroached areas to native grasslands. This paper discusses a number of potential targeting criteria for successful brush management and outlines a methodology for testing the role of steep slope, brush density, and shallow soils on successful use of vegetation replacement for increasing water yield.
\end{abstract}

\section{Introduction}

In the past century, shrub encroachment over the herbaceous rangelands of the southwestern United States has been recognized as a consistent phenomenon that has drastically altered the traditional landscape (Humphrey, 1958). The proliferation of these native but previously non-dominant species has been attributed to a variety of causes including human induced changes and atmospheric adjustment in the form of $\mathrm{CO}_{2}$ enrichment. However, the most important factors for the movement of wooded species from upland slopes to herbaceous lowlands are, more than likely, the increase in range grazing and the reduced frequency of fire events (Van Auken, 2000).

Most of the unwanted brush species have been varieties of juniper (Juniperus ashei and Juniperus pinchotti) and mesquite (Prosopis glandulosa). It is believed that these species may be more taxing upon the available water supply of arid and semiarid regions by way of their interception mechanics and transpiration of water to the atmosphere. Plot scale studies in Texas have indicated a potential per hectare savings of between 375,000 to 935,000 liters of water per year by returning juniper dominated rangeland to herbaceous species (Owens, 1996). By estimating the effects of vegetation replacement over a basin sized scale, many studies have added merit to this notion of brush management as a 
viable option for easing water issues in water-scarce regions (Brown and Raines, 2002; Bednarz et al., 2001; Wu et al., 2001; Red River Authority, 2000).

Arrington et al. (2002) experimented with several scenarios for brush control in an effort to minimize ecological impacts on native animal and aquatic species as well as ensure slope stability and prevent erosion following brush control. The study examined the effects of brush control for increasing water yield while implementing several best management practices (BMPs). These included preventing brush removal on slopes greater than 15\%, instituting a 75-m "no-cut" buffer strip on either side of stream channels, and the selective cutting of brush to allow for wildlife habitat outside of immediate riparian areas. Results indicated that brush management could produce favorable results while still implementing BMPs for protecting local ecology. Thought the study provided very useful information for making brush management ecologically friendly, no attention was given to maximizing removal efficiency for water yield.

The State of Texas has already begun the subsidized removal of brush with hopes of increasing available water through the use of a cost-sharing program regulated through the Texas State Soil and Water Conservation Board (TSSWCB). In 2002, expenditures for program implementation and research totaled \$24 million. Most of the efforts of this program have been aimed at renovating the North Concho River watershed with an expected cost of the additional water averaging $\$ 43$ dollars per million liters. This estimate is less than half of the projected cost of alternate sources of water (TSSWCB, 2002).

However promising the projections may appear, a specific methodology for targeting prime locations for brush management would be beneficial to both economics and hydrology. Currently, though consideration is to be given for local characteristics when choosing sites for brush control, there are no standards for locating ideal areas for treatment (TSSWCB, 2002). If certain characteristics were identified as significantly beneficial to the cause of enhancing water yield, land owners owning property meeting these characteristics could be targeted for the cost-share plan before owners of less desirable land. In effect, brush control funds would be spent in the most effective and efficient manner.

Several characteristics have been either theorized or tested in the past for enhancing the effects of brush removal from range environments. Hibbert (1983) and Bosch and Hewlett (1982) indicated a maximization of effect from vegetation replacement in locations where annual precipitation exceeded a threshold of $450 \mathrm{~mm}$. Steep slopes have also been found to be vital in brush control scenarios where overland flow is a goal (Wright et al., 1976). Wilcox (2002) also proposes three additional factors for maximizing water yield in rangelands: 1) heavy brush cover, 2) shallow soils to allow rapid entry of water to the subsoil, and 3) geologic substructure that allows water to permeate past the root zone to avoid uptake by plants. 
This study aims to examine these characteristics and evaluate their effects upon rangeland hydrology through the use of the Soil and Water Assessment Tool (SWAT) and explain the progress of the continuing research into the targeting of brus $h$ management.

\section{Area of Study}

The region chosen for modeling in this study lies in the Upper Guadalupe River watershed (HUC 12100201) of Central Texas (Figure 1). The more than $3,700 \mathrm{~km}^{2}$ area drains into Canyon Lake near New Braunfels where it enters the Middle Guadalupe River. The region of particular interest lies above the USGS gauging station (USGS \#08167500) at the community of Spring Branch, located west of Canyon Lake, that has a drainage area of nearly $3,400 \mathrm{~km}^{2}$ (USGS, 2003).

Average annual precipitation in the Upper Guadalupe River watershed ranges from approximately $660 \mathrm{~mm}$ along the far western edge of the watershed to as much as 900 $\mathrm{mm}$ in the eastern portion of the basin (PRISM, 2002). Temperatures range from a low mean monthly temperature of $8^{\circ} \mathrm{C}$ in January to a high monthly mean of approximately $27^{\circ} \mathrm{C}$ in July.

Local topography varies between rolling hills and steep rocky outcrops. Land cover is predominately rangeland, most of which is dominated by woody species. These factors encourage ranching rather that traditional farming practices throughout all but the lowland valleys in the basin.

Geology is characterized by fractured substrate consisting largely of Upper and Lower Glen Rose limestone that underlies an Edwards limestone layer in upland areas (Texas Bureau of Economic Geology, 1986 and 1982). These highly porous karst structures can be easily seen below the predominant shallow soil layers. Common soil types throughout the watershed include Eckrant, Tarrant, and Purves series.

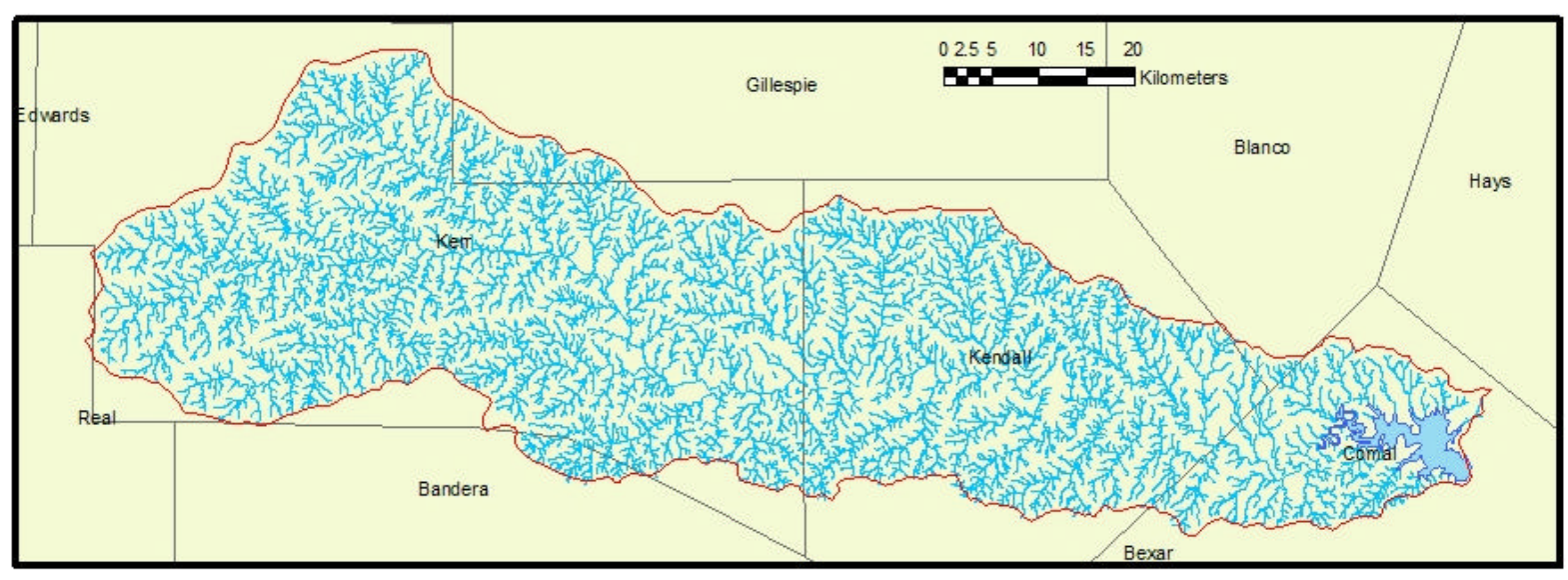

Figure 1: Map of the Upper Guadalupe River Watershed, Texas

\section{Methods}

To effectively evaluate the role of the aforementioned characteristics on water availability changes brought upon by the removal of wooded plants it is necessary to utilize: 1) a model that is capable of simulating hydrology for complex scenarios 
including soil thickness, hillslope, and the effects of land cover for the entire water balance including evaporation and transpiration, and 2) sufficient available data to drive the model that will realistically characterize these factors for a real world scenario. For the needs of this study, the SWAT model was selected because of its comprehensive inclusion of the entire watershed cycle and its ability to accept data from a variety of highly detailed sources. These reasons have also led to the use of SWAT in a number of other brush related studies (Arrington et al., 2002; Bednarz et al., 2000).

Because the study watershed lies within an area receiving more than $450 \mathrm{~mm}$ of precipitation annually, regional effects of climate were disregarded for this study. The entire watershed was selected for simulated treatment without regard to annual rain patterns.

Geology was also neglected as a characteristic for brush removal site selection. Insufficient spatial information exists to properly characterize the influence of this parameter even though the model is capable of incorporating subsurface characteristics through the use of an external subroutine (Sophecleous and Perkins, 2000).

\section{Data collection}

Data selection for the remaining parameters (land cover, soil series, and topography) was conducted with special attention to providing data for the model that would best characterize the conditions that are to be tested. In the case of land cover, no dataset was readily available for use in quantifying the amount of wooded cover. A first priority of the study aimed to create a suitable data product from Landsat ETM+ imagery of the watershed and associated aerial photography in the form of Digital Orthopoto Quadrangles (DOQs). Multiple Resolution Land Cover (MRLC) data was used in conjunction with the multispectral Landsat imagery to train a Bayesian classifier for determining coarse classifications for the study area. These classifications included rangeland, wooded land, agricultural fields, and various urban lancovers. The use of the MRLC dataset, produced from information gathered prior to 1992, and Landsat imagery contemporary to 1999, allowed the creation of an updated land cover dataset that would represent the extent of wooded growth for analysis and also create a general land cover set for use in the SWAT model.

The coarse land cover set described above was further refined with the use of spectrally classified high resolution aerial photography to estimate the amount of wooded cover and define each pixel of range land cover according the amount of observed wooded growth as one of four categories: heavy wooded cover $(>50 \%)$, moderate wooded cover (20$50 \%)$, light wooded cover $(5-20 \%)$, or open range $(<5 \%)$. By further categorizing land cover by the amount of wooded growth present, it is possible to assign a separate curve number to each class to properly represent the effects of varying ratios of brush to herbaceous growth on hydrology.

Additionally, the effects of slope were accounted for in the model to realize its role in increasing water yield from vegetation replacement. Though the SWAT model does not automatically incorporate slope for adjusting curve numbers, this can be conducted 
manually for varying amounts of slope by further characterizing land cover classes by not only coarse description and the amount of wooded cover, but also by the slope present. These further divided classes can then be assigned an adjusted curve number according to the grade of the land (Arrington et al.). For the purpose of this study, slope was determined by the analysis of a composite 30-m National Elevation Dataset (NED) for the Upper Guadalupe River watershed. Regions with a slope of less than 8\% were considered generally flat and received no curve number adjustment. Land with a slope between 8 and 15\% were considered moderate slopes and had an associated curve number that was adjusted to reflect this change. Regions with slopes greater than $15 \%$ were considered steep slopes and the associated curve numbers were adjusted accordingly. Range with heavy, moderate, and light brush, along with herbaceous rangeland covers were all analyzed for slope in this manner and received adjusted curve numbers to ensure effective parame terization of slope effects.

Equation [1] was used to adjust runoff values using the standard moisture condition II curve number $\left(\mathrm{CN}_{2}\right)$, the adjusted curve number for moisture condition III $\left(\mathrm{CN}_{2}\right)$, and the average percent slope of the response unit ( $s l p)$.

$$
C N_{2 S}=\frac{\left(C N_{3}-C N_{2}\right)}{3} \cdot[1-2 \cdot \exp (-13.86 \cdot s l p)]+C N_{2}
$$

Adjustment for $\mathrm{CN}_{3}$ was performed using equation [2] (Neitsch et al., 2001).

$$
C N_{3}=C N_{2} \cdot \exp \left[0.00673 \cdot\left(100-C N_{2}\right)\right]
$$

Soil data was obtained in the form of the NRCS Soil Survey Geographic (SSURGO) database. These datasets, which are comparable to traditional paper soil survey maps) provide the most highly detailed spatial information available for soil types. SSURGO datasets were obtained for Bandera, Comal, Blanco, Gillespie, Kendall, Kerr, and Real counties and mosaiced to provide complete soil coverage for the entire watershed. Because some of the datasets were provided in the new SSURGO 2.0, there was no method available for incorporating the information in the soil database directly into the model as has been performed for the older SSURGO 1.0 datasets (Buland, 2003). To fill in this information gap, tabular information from the Texas State Soil Geographic database (STATSGO) was keyed to the dominant soil series for each spatial map unit in the SSURGO database.

In addition to the information required to characterize the brush covered regions to be modeled in this study, a variety of other inputs were obtained for use in driving the SWAT model. Topographic data for watershed delineation and subbasin parameterization was obtained from the same mosaiced NED used in determining regions of steep slope for curve number adjustment. Hydrography was provided by the National Hydrography Dateset for aid in delineating the stream body. Climate data for precipitation was obtained from the National Climate Data Center for seven stations in and around the Upper Guadalupe River watershed, and three of these stations also 
provided temperature information. A period of record between 1987 and through 2001 was obtained for use in calibration, validation, and simulations. Additional climate data, including missing values from the weather record, was estimated from statistical data using SWAT's weather generator.

\section{Setting up the model}

The SWAT model was prepared for simulation by delineating the Upper Guadalupe River watershed. A subbasin threshold of 2000 ha was used in an effort to optimize model performance and detail. The addition of soil and land cover layers was performed to create Hydrologic Response Units (HRUs) that provided a reasonable assessment of heterogeneity without proving overly taxing on the model engine. Significance thresholds of $1 \%$ and $3 \%$ were set for subbasin land cover content and land cover soil content values, respectively.

For initial simulations, default values for SWAT variables were used until calibration could yield more precise information for the model. An exception to this is the use of a baseflow a value obtained from stream gauge analysis with a baseflow filter. Automated techniques for determining this baseflow vale have been commonly accepted as reliable ways of paramaterizing baseflow in hydrologic models (Arnold et al., 1995). The importance of this parameter in karst hydrologic systems was illustrated by Spruhill et al. (2000) and provided good reason for added attention to this value.

\section{Future Progress}

The research described throughout this paper is ongoing and will require additional effort to yield results for determining the importance of the proposed factors for selection of sites for brush removal.

\section{Model calibration and validation}

Model calibration is currently being performed above USGS gauge \#08165300 on the North Fork of the Guadalupe River; a drainage area of approximately 36,000 ha. The same stream gauging data that was used in baseflow analysis will be used to calibrate the model for channel flow and baseflow on a daily timestep for the period between 1987 and 2001. Upon completion of this process, validation will be performed using the neighboring Johnson Creek watershed that encompasses 29,000 ha (Above USGS gauge \#08166000).

\section{Brush removal simulations}

Upon successful calibration and validation of the SWAT model, simulations will be conducted to evaluate the effects of the hypothesized targeting criteria on water yield following brush management. This will be carried out by modeling the Upper Guadalupe River watershed above Canyon Lake for a control condition, as well as five control scenarios (Figure 2). 


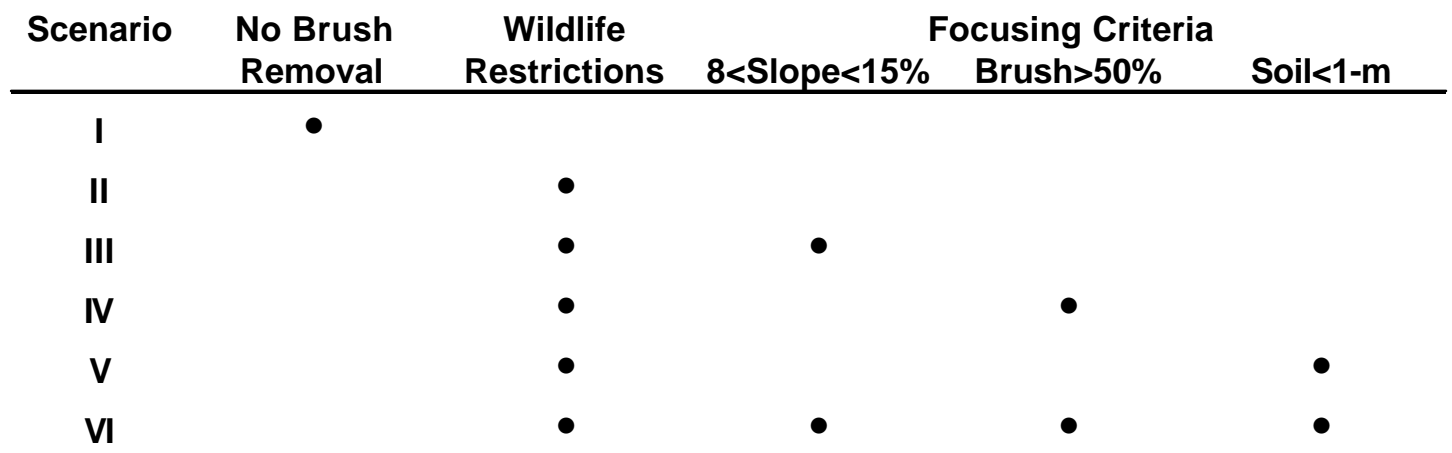

Figure 2: Overview of brush control scenarios.

Scenario I will provide a control condition to compare the brush removal simulations to. The land cover set used will be representative of the Upper Guadalupe River watershed at the time of the remote sensing study and the same as the data used in calibration and validation phases of the model.

Scenario II will demonstrate the most complete removal of heavy and moderate brush throughout the watershed by replacing these land covers with light brush. Consideration for the location of management will only be made for slopes greater than $15 \%$ and $75-\mathrm{m}$ no-cut zones around water bodies where brush will not be removed, as recommended by Arrington et al. (2002). These criteria will be used to limit brush control for all of the following removal schemes. This scenario will simulate removal effects without regard to the focusing criteria discussed by this paper.

Scenario III will limit brush clearing to only the heavy and moderate brush found on slopes between 8 and 15\%. Scenario IV will explore the effect of brush cover on removal efficiency by removing only heavy brush from the watershed and leaving moderate brush behind. Soil depth will be examined in Scenario V by limiting control to regions with shallow soils of less than 1-m in depth. Finally, Scenario VI will take into account all of the proposed criteria by selecting only regions of moderate slope, heavy brush, shallow soil, and no wildlife restrictions. The percentages of heavy, moderate, and light brush present in each scenario are illustrated in Figure 3.

\begin{tabular}{cccc} 
Scenario & Heavy Brush & Moderate Brush & Light Brush \\
\hline I & 54.36 & 27.38 & 7.47 \\
II & 14.3 & 6.01 & 69.27 \\
III & 48.09 & 24.31 & 17.17 \\
IV & 14.3 & 27.19 & 48.09 \\
V & 26.07 & 12.16 & 51.35 \\
VI & 49.47 & 27.19 & 12.91
\end{tabular}

Figure 3: Percent of heavy, moderate, and light brush land covers for each scenario.

Analysis will be conducted by observing the difference in water yield (including groundwater recharge and surface flow) between the scenario I (control) condition and the experimental condition on a basis of water yield increase per hectare of treatment. The proposed focusing criteria will be judged on a basis of how effective they are at targeting the most important brush impaired locations for control. 


\section{Conclusions}

This paper presents a list of potential criteria for brush control site selection to increase water yield in semiarid and arid range environments that are impaired by wooded species. The SWAT model is evaluated for use in determining the importance of three of the proposed rules and it is demonstrated that the model is capable of simulating the hydrology to a necessary degree to ascertain the importance of slope, brush cover density, and soil depth in choosing sites for management.

Additionally, a plan is described for using the model to evaluate these criteria on a basis of their efficiency for locating the most important locations for management for water yield. Completion of the prescribed course of action will prove to be a benefit to understanding the role of certain factors on the effectiveness of vegetation replacement as a BMP and also the way that brush management should be approached for maximum benefit.

\section{References}

Arnold, J.G., P.M. Allen, R. Muttiah, and G. Bernhardt. 1995. Automated base flow separation and recession analysis techniques. Ground Water. 33(6):1010-1018.

Arrington, D.A, R. Conner, W. Dugas, S. Hejl, D. Magness, R. Muttiah, K. Olenick, W. Rosenthal, R. Srinivasan, K. O. Winemiller, M. Zinn, N. Wilkins, C. Amonett, S. Bednarz, T. Dybala, R. Griffith, and H. Jarboe. 2002. Ecosystem and wildlife implications of brush: management systems designed to improve water yield. TR-201. College Station, Tex.: Texas Water Resources Institute.

Bednarz, S.T., T. Dybala, R.S. Muttiah, W. Rosenthal, W.A. Dugas. 2000. Brush management/water yield feasibility studies for eight watersheds in Texas. TR-182. College Station, Tex.: Texas Water Resources Institute.

Bosch, J.H., and J.D. Hewlett. 1982. A review of catchment experiments to determine the effect of vegetation changes on water yield and evapotranspiration. Journal of Hydrology. 55:3-23.

Brown, D.S., and T.H. Raines. 2002. Simulation of flow and effects of bestmanagemment practices in the Upper Seco Creek basin, couth-central Texas, 1991-98. Water-Resources Investigations Report 02-4249. Austin, Tex.: U.S. Geological Survey.

Buland, D. 2003. SSURGO County-level soils data with the SWAT watershed model. Temple, Tex.: Blackland Research Center. Available at: waterhome.brc.tamus.edu/NRCSdata/SWAT_SSURGO. Accessed: 3 April 2003.

Hibbert, A.R. 1983 Water yield improvement potential by vegetation management on western rangelands. Water Resources Bulletin. 19:375-381.

Humphrey, R.R. 1958. The desert grassland: a jistory of vegetational change and an analysis of causes. The Botanical Review. XXIV(4):193-252. 
Neitsch, S.L., J.G. Arnold, J.R. Kiniry, and J.R. Williams. 2001. Soil and water assessment tool theoretical documentation. Temple, Tex.: Blackland Research Center.

Owens, M.K. 1996. The roll of leaf and canopy-level gas exchange in the replacement of Quercus virginiana (Fagaceae) by Juniperus ashei (Cupressaceae) in semiarid savannas. American Journal of Botany. 83:617-623.

PRISM. 2002. Climate mapping with prism. Coravallis, Or.: Oregon StateUniversity. Available at: www.ocs.orst.edu/prism/prism_new.html. Accessed 23 September 2002.

Red River Authority. 2000. Assessment of Brush Management/Water Yield Feasibility for the Wichita River Watershed Above Lake Kemp, Hydrologic Evaluation and Feasibility Stud y. Wichita Falls, Tex.: Red River Authority of Texas.

Sophocleous, M., and S.P. Perkins. 2000. Methodology and application of combined watershed and ground-water models in Kansas. Journal of Hydrology. 236:185-201.

Spruhill, C.A., S.R. Workan, and J.L. Taraba. 2000. Simulation of daily and monthly stream discharge from small watersheds using the SWAT model. Transactions of the ASAE. 43(6):1431-1439.

Texas Bureau of Economic Geology. 1986. Geologic atlas of Texas, Llano sheet. Austin, Tex.: Texas Bureau of Economic Geology.

Texas Bureau of Economic Geology. 1982. Geologic atlas of Texas, San Antonio sheet. Austin, Tex.: Texas Bureau of Economic Geology.

TSSWCB. 2002. State brush control plan. Temple, Tex.: Texas State Soil and Water Conservation Board.

Van Auken, O.W. 2000. Shrub invasions of North American semiarid grasslands. Annual Review of Ecology and Systematics. 31:197-215.

USGS. 2003. Daily streamflow for the nation. Washington, D.C.: United States Geological Survey. Available at: www.usgs.gov. Accessed: 12 May 2003.

Wilcox, B.P. 2002. Shrub control and streamflow on rangelands: A process based viewpoint. Journal of Range Management. 55:318-326.

Wright, H.A., F.M. Churchill, and W.C. Stevens. 1976. Effect of prescribed burning on sediment, water yield, and water quality. Journal of Range Management. 29(4):294-298.

Wu, X.B., E.J. Redeker, and T.L. Thurow. 2001. Vegetation and water yield dynamics in an Edwards Plateau watershed. Journal of Range Management. 54:98-105. 